\title{
MICROSTRUCTURE AND MECHANICAL PROPERTIES OF COLD-DEFORMED PURE TITANIUM AND TITANIUM GRADE 5
}

\author{
MIKROSTRUKTURA IN MEHANSKE LASTNOSTI HLADNO \\ DEFORMIRANEGA ČISTEGA TITANA IN TITANA ČISTOSTI 5
}

\author{
Kateřina Mertová*, Michal Duchek \\ COMTES FHT a.s., Průmyslová 995, Dobřany, 334 41, Czech Republic \\ Prejem rokopisa - received: 2019-07-16; sprejem za objavo - accepted for publication: 2020-06-11
}

doi:10.17222/mit.2019.162

\begin{abstract}
The effects of cold deformation on commercially pure titanium Grade 2, titanium Grade 4 and titanium Grade 5 (TiAl6V4) were explored and compared. The possible use of these wrought materials is discussed. They were worked by rotary swaging at ambient temperature. The purpose was to impart high strengthening, while maintaining sufficient ductility for further processing. The two pure titanium grades were cold deformed with a total area reduction of $90 \%$. Only minor surface damage was observed on the workpieces. However, in titanium Grade 5, the need for in-process annealing between the cold-deformation steps was identified. High strengthening was obtained in all the materials. Titanium Grade 4 and the titanium alloy had ultimate strengths in excess of $1000 \mathrm{MPa}$ and $1400 \mathrm{MPa}$, respectively. The hardness profile in the transverse direction was measured and discussed. The interior of the wires had higher hardness than the surface. The microstructure investigation helped to reveal structural changes and clarify the material's properties.

Keywords: cold deformation, titanium, pure titanium, titanium grade 5
\end{abstract}

Avtorji tega prispevka so raziskovali in primerjali vplive hladne deformacije na komercialno čisti titan, titan čistosti 2, čistosti 4 in 5 (TiAl6V4). Raziskovalci so tudi analizirali možnosti uporabe teh materialov. Hladno deformacijo so izvajali s postopkom rotacijskega kovanja pri sobni temperaturi. Namen predelave izbranih materialov $\mathrm{s}$ tem postopkom je bil doseganje njihove visoke trdnosti, vendar pri tem ohraniti še zadovoljivo duktilnost za njihovo nadaljnjo obdelavo. Dve vrsti čistega titana so hladno deformirali z $90 \%$ stopnjo deformacije (zmanjšanjem celotnega preseka). Na preizkušancih so po hladni deformaciji opazili le zanemarljive površinske poškodbe. Medtem, ko je bilo potrebno titan čistosti 5 med posameznimi stopnjami hladne deformacije žariti. Pri vseh izbranih materialih je prišlo do močne utrditve oziroma povišanja mehanske trdnosti. Pri titanu čistosti 4 in titanovi zlitini se je natezna trdnost povišala na $1000 \mathrm{MPa}$ oziroma $1400 \mathrm{MPa}$. Avtorji so izmerili in komentirali še profil trdote $\mathrm{v}$ prečni smeri. Notranjost vlaken je imela višjo trdoto kot površina. Karakterizacija mikrostrukture je avtorjem pomagala ugotoviti do kakšnih mikrostrukturnih sprememb je prišlo med hladno deformacijo in posledično do sprememb mehanskih lastnosti.

Ključne besede: hladna deformacija, titan, čisti titan, titan čistosti 5

\section{INTRODUCTION}

Materials engineers can choose from four titanium chemistries specified by standards, which are identified by numbers from 1 to 4 . With an increasing number, the content of impurities rises, including both substitutional and interstitial elements. The following are those of the greatest interest: iron, carbon, and several gases: oxygen, hydrogen and nitrogen. These elements have the strongest impact on the solid-solution strengthening of $\alpha$-phase in titanium. The $\alpha$-phase has a hexagonal close-packed crystal structure. This structure does not offer many slip systems for plastic deformation. It has one slip plane, which is the basal plane (0001), with the slip directions [2110]. Hence, a total of three slip systems is available. This structure is expected to deform primarily by twinning, particularly at small strains, a mechanism which is based on partial dislocation glide. ${ }^{1}$

Titanium Grade 2, titanium Grade 4 and a titanium Grade 5 (Ti Grade 5) are widely used for human im-

*Corresponding author's e-mail:

katerina.mertova@comtesfht.cz (Kateřina Mertová) plants, thanks their biocompatibility. With its excellent biological and biomechanical properties, commercially pure titanium has become the material of choice for dental applications. Yet, it offers poorer mechanical properties than Ti Grade 5. Generally, high strength values are desired, namely for dental implants, but Ti Grade 5 contains potentially cytotoxic elements, such as aluminium and vanadium. In order to improve the mechanical properties of pure titanium and bring them closer to those of Ti Grade 5, more effective processing techniques should be developed. Tensile strength and fatigue performance can be improved for instance by SPD (severe plastic deformation) processes. Those lead to rapid grain refinement and thus improve the mechanical properties. ${ }^{2-4}$

Rotary swaging is a forming technology for reducing the cross-section of tubes, rods and wires. It is widely used for the sequential reduction of products of circular cross-section. Its main advantages include a short time cycle, good final surface and dimensional tolerances. The total reduction is controlled by selecting the forging die and the size of the feedstock. The workpiece is deformed locally at high frequency and favourable strain 
K. MERTOVÁ et al.: MICROSTRUCTURE AND MECHANICAL PROPERTIES OF COLD-DEFORMED PURE TITANIUM ...

Table 1: Chemical composition of the materials, in mass fractions $(w / \%)$

\begin{tabular}{|c|c|c|c|c|c|c|c|c|}
\hline Material & $\mathrm{Fe}$ & $\mathrm{O}$ & $\mathrm{C}$ & $\mathrm{H}$ & $\mathrm{N}$ & $\mathrm{Al}$ & $\mathrm{V}$ & $\mathrm{Ti}$ \\
\hline Ti Grade 2 & 0.046 & 0.12 & 0.023 & 0.0026 & 0.0076 & - & - & bal. \\
\hline Ti Grade 4 & 0.500 & 0.40 & 0.010 & 0.0125 & 0.0050 & - & - & bal. \\
\hline Ti Grade 5 & 0.190 & 0.11 & 0.080 & $<0.006$ & 0.0131 & 6.22 & 4.23 & bal. \\
\hline
\end{tabular}

states can be achieved. Rotary swaging is considered by many researchers as one of the severe plastic deformation (SPD) processes. ${ }^{5-7}$

In this study, the influence of the cold deformation of commercially pure titanium Grade 2 and Grade 4 and the commonly known titanium alloy titanium Grade 5 is discussed.

\section{EXPERIMENTAL PART}

The composition of the feedstock was measured using a Bruker Q4 Tasman optical emission spectrometer. The values are given in Table 1. The wires were rotary swaged at ambient temperature, achieving a total area re- duction of $90 \%$. The cross-sectional area was reduced by $20 \%$ in each pass. The initial and final diameters of the feedstock were $10 \mathrm{~mm}$ and $3.28 \mathrm{~mm}$, respectively. The frequency of the forging was $24 \mathrm{~Hz}$ and the wire was fed at approximately $3 \mathrm{~m} / \mathrm{min}$.

After grinding and polishing, the metallographic specimens were etched with Kroll's reagent. The optical microscope Carl Zeiss - Observer.Z1m and bright-field illumination were used for the microstructure observation. The tensile testing was carried out in an electromechanical testing machine. The tests followed the EN ISO 6892-1 standard. Extension was measured with a mechanical extensometer. Yield stress at $0.2 \%$ deformation (OYS), ultimate stress (UTS), elongation $\left(\mathrm{A}_{5}\right)$ and reduc-
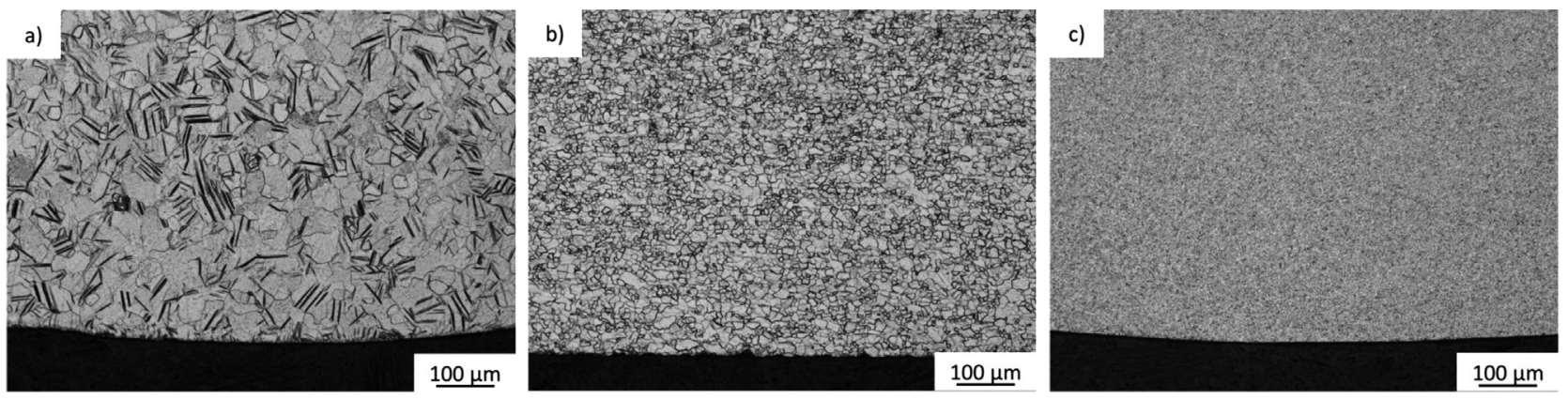

Figure 1: Feedstock microstructures on transverse metallographic sections: a) Ti Grade 2, b) Ti Grade 4 and c) Ti Grade 5

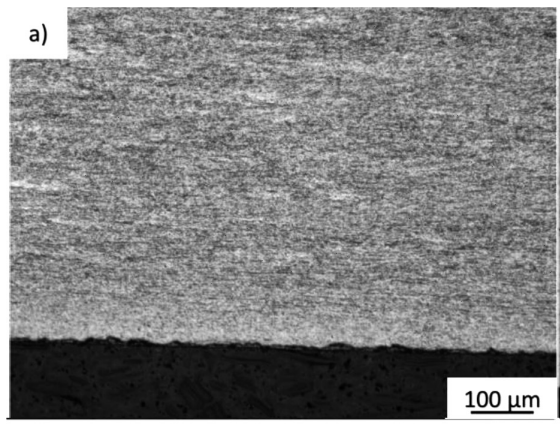

\section{b)}
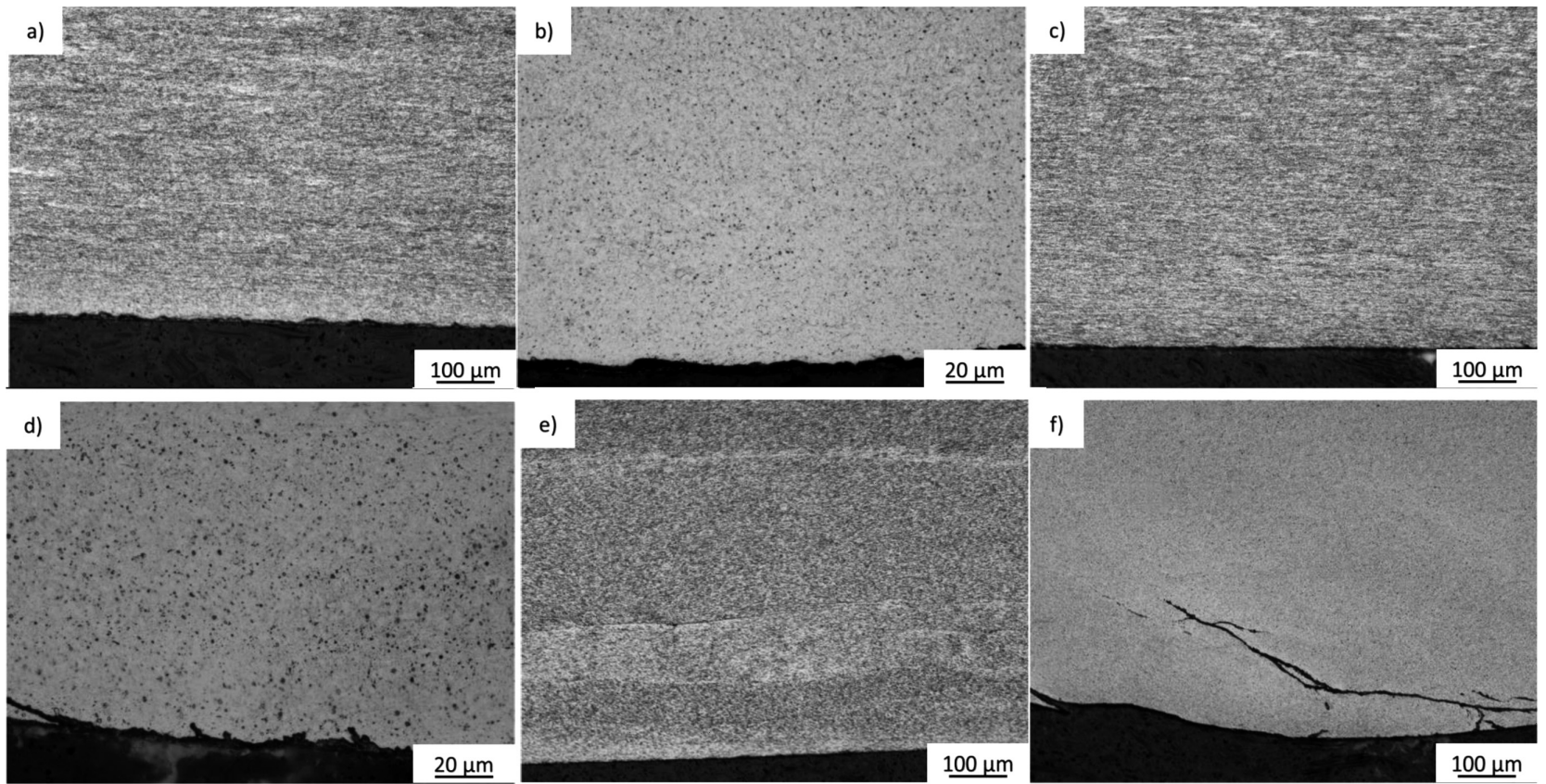

Figure 2: Micrographs of the materials after $90 \%$ area reduction: a) Ti Grade 2 - longitudinal section, b) Ti Grade 2 - transverse section, c) Ti Grade 4 - longitudinal section, d) Ti Grade 4 - transverse section, e) Ti Grade 5 - longitudinal section, and f) Ti Grade 5 - transverse section 
tion of area (RA) were calculated. The average values from three valid measurements are plotted in the results section. The Vickers microhardness HV0.3 was measured by means of Durascan 50 automatic hardness tester across the cross-section of the products.

\section{RESULTS}

The microstructure of the feedstocks is shown in Figure 1. Micrographs of specimens after the final $(90 \%)$ area reduction are presented in Figure 2. On longitudinal metallographic sections, the gradual extension of the grains with increasing deformation was observed in each material, accompanied by a reduction of the grain cross section. Significant grain refinement was found on transverse sections with the mean grain size estimated to be under $1 \mu \mathrm{m}$ in all the materials. The surface of the pure titanium contains no cracks or large defects. Ti Grade 5 contains cracks in the surface after $90 \%$ area reduction, (Figure 2f). No signs of recovery were found. A detail of the microstructure of Ti Grade 2 after cold deformation showing deformation twins is presented in Figure 3. The

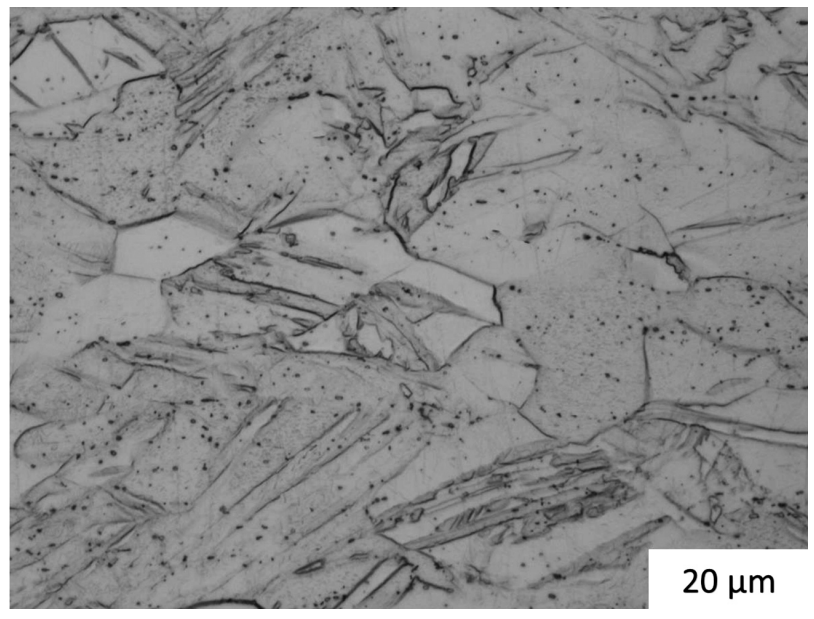

Figure 3: Detail micrograph of Ti Grade 2 after $20 \%$ area reduction

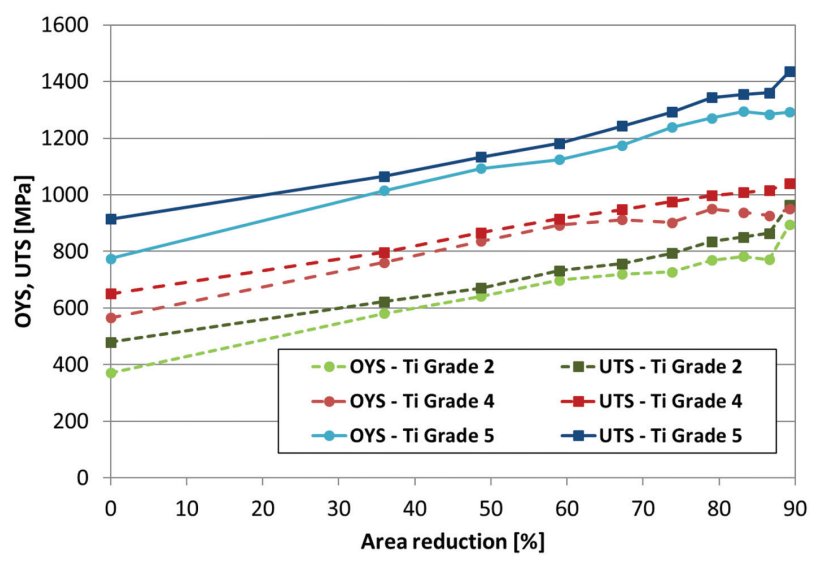

Figure 4: Offset yield strength and ultimate yield strength (OYS, UTS) vs. area reduction

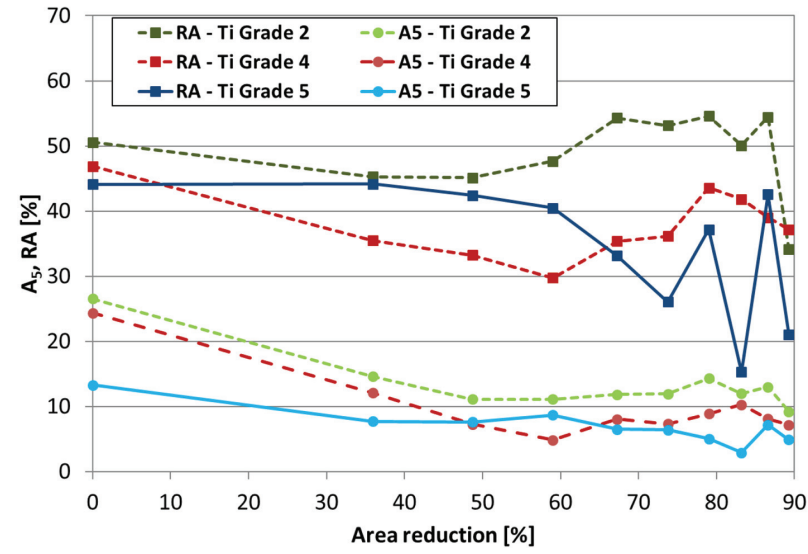

Figure 5: Elongation and reduction of area $\left(A_{5}, R A\right)$ vs. area reduction by forming

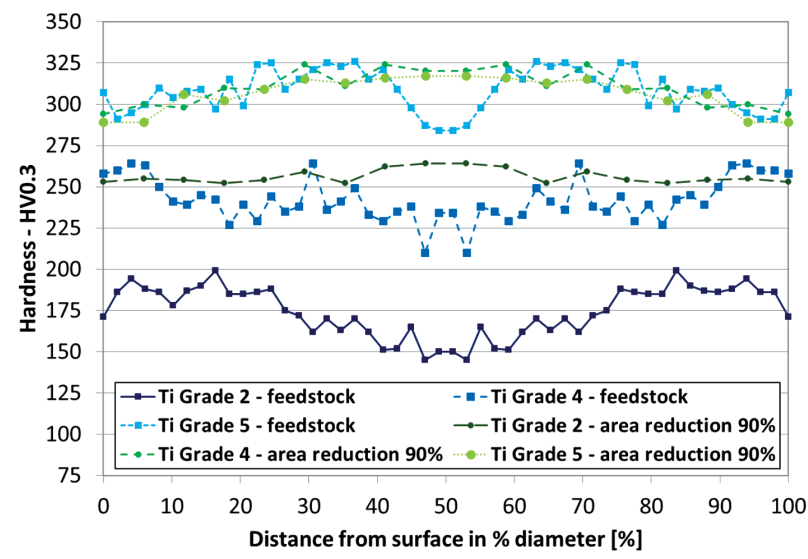

Figure 6: Vickers hardness across the cross-section

deformation twins are characteristic of pure titanium at a smaller amount of cold deformation.

With each reduction, the ultimate strength and yield strength increased thanks to structure refinement, but the ductility decreased, as seen in the plot in Figure 4. Ti Grade 4 and Ti Grade 5 had post-forged ultimate strengths above $1000 \mathrm{MPa}$ and $1400 \mathrm{MPa}$, respectively. The elongation decreased significantly during the first two deformation steps and then plateaued below $10 \%$ for both Ti Grade 4 and Ti Grade 5. Cold-worked Ti Grade 2 wires had a higher elongation, in the range of 10 to $15 \%$, (Figure 5). Figure 6 shows a hardness profile on the cross-section of wires with $0 \%$ (feedstock) and $90 \%$ area reductions.

The hardness of the feedstocks is higher near the surface than in the centre. In the cold-deformed rotary-swaged products, the higher hardness is in the interior.

\section{DISCUSSION}

Cold reduction tends to increase the strength and reduce the ductility of materials. In Ti Grade 2, the increment of strength due to the cold deformation was larger than in Ti Grade 4. Its lower content of interstitial ele- 
ments appears to allow for a greater accumulation of dislocations in the solid solution. However, higher strength was found in Ti Grade 4 in which strengthening is mainly due to interstitial elements, which are more abundant in Ti Grade 4 than in Ti Grade 2. In pure titanium, the dominating deformation mechanism was twinning. The largest strengthening occurred in Ti Grade 5. The main reason is its larger content of alloying elements. In addition, Ti Grade 5 showed the smallest decrease in elongation. This titanium Grade 5 contains both alpha and beta phases. The beta phase possesses good formability thanks to which the material retains ductility better than pure titanium. However, since the initial elongation in Ti Grade 5 is approx. $13 \%$, Ti Grade 5 loses the capacity for plastic deformation earlier than pure titanium. The loss of ductility in a material that was only worked by rotary swaging can lead to poorer fatigue properties.

In these rotary-swaged materials, the grains became elongated in the longitudinal direction, and therefore they did not reach nano size. In general, ultrafine grains cannot be attained in rotary-swaged materials. Large cracks formed in the surface of the mechanically worked Ti Grade 5, which calls for in-process annealing between the individual cold deformation steps. The hardness of the feedstocks is higher near the surface than in the centre. This is due to its processing history, as the wire was made by rolling. Rolling leads to greater work hardening near the surface. ${ }^{9}$ The strain magnitude is largest in the centre of the cold-worked wire's cross-section. With increasing amount of strain, the distribution of hardness on the cross-section becomes more uniform because of intensive work-hardening.

Considering these drawbacks, it would be useful to combine one additional process and rotary swaging to work these materials. This could produce a material with high strength and good ductility suitable for further processing. A handful of earlier studies focused on using an SPD (severe plastic deformation) process and rotary swaging for forming commercially pure titanium. ${ }^{10-12}$

\section{CONCLUSIONS}

Pure titanium of two Grades 2 and 4 was successfully cold deformed with a total area reduction of $90 \%$. Only minor damage was found on the surface of these workpieces. With titanium Grade 5, there proved to be a need for in-process annealing between the cold-deformation steps. In all the materials, the grains became elongated in the longitudinal direction and refined in the transverse direction. Based on the present results, the rotary swaging of titanium does qualify as an SPD process, although several other reports suggest so. In order to obtain a titanium material for an implant with high strength and good ductility suitable for further processing, it appears desirable to combine one additional process with rotary swaging.

\section{Acknowledgment}

This paper was created under the project TH03010354 - Graded and functionally-structured long-life coxal implant (Gradientní funkčně strukturovaný kyčelní implantát s vysokou životností.)

\section{REFERENCES}

${ }^{1}$ M. Duchek, J. Palán, T. Kubina, Mechanical and Microstructural Properties of Rotary-Swaged Wire of Commercial-Purity Titanium, International Journal of Chemical, Materials and Biomolecular Sciences, 13(2019) 7, 1-5, doi:10.5281/zenodo.3300423

${ }^{2}$ F. Froes, M. Qian, Titanium in Medical and Dental Applications, Woodhead Publishing, $1^{\text {nd }} e d, 2018,654$, doi:10.1016/C2016-003591-X

${ }^{3}$ J. Palán, L. Maleček, J. Hodek, M. Zemko, J. Dzugan, Possibilities of biocompatible material production using conform SPD technology, Archives of Materials Science and Engineering, 88 (2017) 1, 5-11, doi:10.5604/01.3001.0010.7746

${ }^{4}$ J. Palán, M. Zemko, The high strength biocompatible wires of commercially pure titanium, Archives of materials science and engineering, 11 (2017) 6, 477-481, doi:10.5281/zenodo.1131932

${ }^{5}$ J. H. Jang, W.-H. Kwon, S.-H. Chun, Y.-H. Moon, Reliability analysis of process-induced cracks in rotary swaged shell nose part, Journal of Mechanical Science and Technology, 26, (2012), Korean Soc Mech Engn (KSME); Japan Soc Mech Engn (JSME), doi: $10.1007 / \mathrm{s} 12206-012-0535-\mathrm{Z}$

${ }^{6}$ S. J. Lim, H.-J. Choi, C.-H. Lee, Forming characteristics of tubular product through the rotary swaging process, Journal of Materials Processing Technology, 209 (2009) 1, 283-288, doi:10.1016/ j.jmatprotec.2007.08.086

${ }^{7}$ Q. Zhang, K. Jin, D. Mu, Tube/tube joining technology by using rotary swaging forming method, Journal of Materials Processing Technology, 214 (2014) 10, 2085-2094, doi:10.1016/j.jmatprotec. 2014.02.002

${ }^{8}$ K. Mertová, P. Salvetr, M. Duchek, Comparison of cryogenic and cold deformation of commercially pure titanium, in press $(\mathbf{2 0 2 0})$, doi:10.1016/j.matpr.2019.12.324

${ }^{9}$ B. Jansson, M. Rolfson, A. Thuvander, A. Melander, C. Wullimann, Calculation of microstructure and hardness of hot rolled steel bars. Mater. Sci. Technol., 7 (2014) 118-128, doi:10.1179/mst.1991. 7.2.118

${ }^{10}$ J. Palán, R. Procházka, M. Zemko, The microstructure and mechanical properties evaluation of UFG Titanium Grade 4 in relation to the technological aspects of the CONFORM SPD process, Procedia Engineering, 207 (2017), 1439-1444, doi:10.1016/j.proeng.2017. 10.910

${ }^{11}$ J. Palán, R. Procházka, J. Džugan, Comprehensive Evaluation of the Properties of Ultrafine to Nanocrystalline Grade 2 Titanium Wires, Materials, 11 (2018), 2522, doi:10.3390/ma11122522

${ }^{12}$ K. Mertová, J. Palán, M. Duchek, T. Studecký, J. Džugan, I. Poláková, Continuous Production of Pure Titanium with Ultrafine to Nanocrystalline Microstructure, Materials, 13 (2020), 336, doi:10.3390/ma13020336 